\title{
Intensitas dan Persentase Serangan Beberapa Penyakit Utama Pada Tanaman Sawit (Elaeis guineensis Jacq.) di Desa Tebing Tinggi Kecamatan Mara Sebo Ulu Kabupaten Batanghari
}

\author{
Yuza Defitri* \\ Fakultas Pertanian Universitas Batanghari \\ Jl. Slamet Ryadi, Broni-Jambi \\ *Correspondence email: yuza.defitri@unbari.ac.id
}

\begin{abstract}
Abstrak. Penelitian ini telah dilaksanakan di Perkebunan kelapa sawit rakyat di Desa Tebing Tinggi Kecamatan Mara Sebo Kabupaten Batanghari pada bulan Maret sampai Juni 2021. Tujuan penelitian adalah untuk mengamati penyakit yang ada pada perkebunan kelapa sawit, persentase dan intensitas serangan penyakit tersebut. Penelitian ini menggunakan metode survey dengan pengambilan sampel secara acak di 3 lokasi perkebunan rakyat dalam desa Tebing Tinggi yaitu 20 tanaman sampel masingmasing kebun. Amati semua tanaman dan dihitung berapa jumlah yang bergejala penyakit. Kemudian dihitung persentase dan intensitas serangan penyakit. Diambil bagian sampel tanaman yang sakit dibungkus dalam koran lembab untuk diidentifikasi di Laboratorium Dasar Unbari. Hasil penelitian menunjukkan bahwa di desa Tebing Tinggi Kecamatan Mara Sebo Ulu ditemukan persentase serangan penyakit Bercak Daun Curvularia yang disebabkan jamur Curvularia sp yang tertinggi ditemukan di lahan P2 sebesar $40 \%$, serangan penyakit Bercak Daun Drechslera yang disebabkan jamur Drechslera sp yang tertinggi ditemukan di lahan P2 sebesar 35\%, serta serangan penyakit Tajuk (Crown Desease) yang disebabkan jamur Fusarium sp tertinggi ditemukan di lahan P3 sebesar $20 \%$. Adapun Intensitas serangan penyakit yang ditemukan di Desa Tebing Tinggi yaitu, intensitas serangan penyakit Bercak Daun Curvularia yang disebabkan jamur Curvularia sp di desa Tebing Tinggi adalah 28,75 \%, intensitas penyakit Bercak Daun Drecshlera yang disebabkan jamur Drechslera sp adalah 26,25 \% dan intensitas penyakit Tajuk Crown Disease adalah $6,6 \%$.
\end{abstract}

Kata kunci: Persentase; intensitas serangan penyakit

Abstract. This research was carried out in smallholder oil palm plantations in Tebing Tinggi Village, Mara Sebo District, Batanghari Regency from March to June 2021. The purpose of the study was to observe the diseases that exist in oil palm plantations, the percentage and intensity of the disease attacks. This study used a survey method with random sampling at 3 locations of smallholder plantations in Tebing Tinggi village, namely 20 sample plants from each garden. Observe all plants and count how many are symptomatic of the disease. Then calculated the percentage and intensity of disease attacks. Samples of diseased plants were taken and wrapped in damp newspapers for identification at the Unbari Basic Laboratory. The results showed that in Tebing Tinggi village, Mara Sebo Ulu district, the highest percentage of Curvularia leaf spot disease caused by the fungus Curvularia sp was found in P2 area at 40\%, Drechslera leaf spot disease attack caused by Drechslera sp fungus was highest in P2 land. by 35\%, and the highest attack of crown disease (Crown Disease) caused by the fungus Fusarium sp. was found in P3 land by 20\%. The intensity of disease attacks found in Tebing Tinggi Village, namely, the intensity of the attack of Curvularia Leaf Spot disease caused by the fungus Curvularia sp in Tebing Tinggi village was 28.75\%, the intensity of Drecshlera Leaf Spot disease caused by Drechslera sp fungus was 26.25\% and Crown disease crown disease is $6.6 \%$.

Keyword: Percentage; intensity of disease attacks

\section{PENDAHULUAN}

Tanaman kelapa sawit (Elaeis guineensis Jacq.) adalah salah satu jenis tanaman perkebunan yang sangat dominan di Indonesia. Tanaman kelapa sawit berperan penting dalam meningkatkan devisa negara dan juga dengan adanya perkebunan kelapa sawit menciptakan lapangan pekerjaan bagi masyarakat. Tanaman kelapa sawit merupakan tanaman yang mempunyai nilai ekonomis yang sangat tinggi, dan juga kelapa sawit merupakan sumber minyak nabati yang bagus di dunia, sehingga permintaan terhadap produk kelapa sawit ini sangat besar. Semakin meningkatnya permintaan bahan minyak dari kelapa sawit, juga menjadi peranan penting bagi perekonomian negara Indonesia (Sitinjak, 2018).
Provinsi Jambi merupakan salah satu daerah penghasil tanaman sawit. Luas areal perkebunan tanaman kelapa sawit di Provinsi Jambi dari tahun 2006 sampai tahun 2017 terus mengalami peningkatan .Tercatat pada tahun 2006 luas areal perkebunan sawit adalah 362.935 Ha dan sampai ditahun 2017 telah lebih dari 500.000 Ha. Luas areal perkebunan sawit di Kecamatan Mara Sebo hanya 16.771,45 Ha dengan produksi pada tahun 2017 adalah 1.031.215 Ton untuk Provinsi Jambi sedangkan Kecamatan Mara Sebo produksinya jauh lebih rendah yaitu hanya 29.252 Ton (Biro Pusat Statistik Provinsi Jambi, 2018).

Rendahnya produksi tanaman kelapa sawit salah satunya disebabkan serangan penyakit.. Penyebab penyakit yang sering dijumpai pada tanaman kelapa 
sawit adalah jamur. Sedangkan bakteri atau virus jarang dijumpai dan tidak menimbulkan kerusakan yang berarti (Semangun, 2000).

Berikut ini ada beberapa jenis penyakit yang menyerang tanaman kelapa sawit di perkebunan yaitu, Busuk Pangkal Batang, Busuk Tandan, penyakit tajuk (crown disease), Busuk Daun (antraknose), Bercak Daun dan lain lain (Semangun, 2000).

Penyakit Busuk Pangkal Batang gejalanya dapat diketahui dari mahkota pohon. Pohon yanhg sakit mempunyai janur daun yang belum membuka, spear leaves lebih banyak dari pada biasa. Daun daun berwarna pucat, yang tua jadi layu, patah pada pelepahnya dan menggantung di sekitar batang. Hal ini bukan gejala yang khas karena gejala yang sama juga disebabkan terhambatnya pengangkutan air, hara mineral ke mahkota. Gejala yang khas, sebelummnya terbentuknya badan buah jamur dengan adanya pembusukkan pada pangkal batang (Semangun, 2000).

Penyakit Busuk Tandan gejalanya terlihat pada permukaan tandan buah dimana terdapat benang benang jamur berwarna putih mengkilat. Miselium banyak terdapat pada pangkal tandan yang melekat pada pelepah daun. Jamur masuk ke dala daging buah (mesocarp) yang menyebabkan busuk basah, buah berwarna coklat muda. Pembusukkan dapat meningkatkan kadar asam lemak buah karena ada liposis (Semangun, 2000).

Penyakit Tajuk/mahkota (Crown Disease) sering dijumpai di kebun yang belum menghasilkan, dan merupakan penyakit yang menyolok di sini. Pada Umumnya penyakit hanya terdapat di kebun yang berumur $1-4$ tahun setelah penanaman di lapangan (Agrios, 1999).

Penyakit Bercak Daun. Penyakit ini dapat disebabkan oleh jamur Curvularia dan Drechslera. Serangan dapat terjadi selama periode kering dan basah. Gejala awal tampak berupa bintik kuning pada daun tombak atau yang telah membuka, bercak membesar dan menjadi agak lonjong dengan panjang 7-8 mm berwarna coklat terang dengan tepi kuning atau tidak, bagian tengah bercak kadang kala tampak berminyak.

Pada gejala lanjut bercak menjadi nekrosis, beberapa bercak menyatu membentuk bercak besar tak beraturan. Pada beberapa kasus bagian tengah bercak mengering, rapuh, berwarna kelabu atau coklat muda.

Penyakit Busuk daun (Antraknosa) Penyakit antraknosa merupakan sekumpulan nama infeksi pada daun bibit-bibit muda, yang disebabkan oleh 3 genera jamur patogenik, yaitu Botryodiplodia spp., Melanconium elaeidis dan Glomerella cingulata. Spora dihasilkan di dalam piknidia atau aservuli, menyebar dengan bantuan angin atau percikan air siraman atau hujan. Penyakit ini telah dilaporkan terdapat di berbagai perkebunan kelapa sawit di Indonesia (Sianturi, 2001).

\section{METODE}

Penelitian ini telah dilaksanakan di Desa Tebing Tinggi Kecamatan Mara Sebo Ulu Kabupaten Batanghari dan Laboratorium Universitas Batanghari selama 6 bulan (Februari s/d Agustus) 2021.

Pengamatan secara langsung dilakukan di 3 lokasi (kebun) masing-masingnya diamati secara acak sebanyak 20 tanaman. Data yang diperoleh di lapangan adalah gejala penyakit, jumlah tanaman yang terserang, persentase dan intensitas serangan penyakit.

Pengamatan di Laboratorium adalah dengan melakukan identifikasi penyakit yang menyerang tanaman kelapa sawit dengan metode moist chamber dan melihat pathogen secara mikroskopis.

\section{Persentase Tanaman Terserang}

Persentase tanaman terserang dapat dihitung dengan rumus :

$$
\begin{aligned}
& \mathbf{P}=\mathbf{n} / \mathbf{N} \mathbf{x} \mathbf{1 0 0} \% \\
& \text { Keterangan: } \\
& \mathrm{P} \quad \text { = Persentase Tanaman terserang }(\%) \\
& \mathrm{n} \quad \text { = Jumlah Tanaman yang terserang } \\
& \mathrm{N} \quad \text { = Jumlah Tanaman yang diamati }
\end{aligned}
$$

\section{Intensitas Serangan Penyakit}

$$
I=\frac{n i \cdot V i}{N \cdot V} \times 100 \%
$$

Keterangan :

$$
\begin{array}{ll}
\mathrm{I} & =\text { Intensitas Serangan penyakit }(\%) \\
\mathrm{ni} & =\text { Jumlah Tanaman yang terserang } \\
\mathrm{Vi} & =\text { Nilai Skor Serangan } \\
\mathrm{N} & \text { = Jumlah Tanaman Keseluruhan } \\
\mathrm{V} & =\text { Skor Tertinggi }
\end{array}
$$

Tingkat skor yang digunakan adalah

$0=$ Sehat

$1=$ Sangat Ringan $(1-25 \%$ rusak $)$

$2=$ Ringan $(26-50 \%$ rusak $)$

$3=$ Sedang $(51-75 \%$ rusak $)$

$4=$ Berat $(75-100 \%$ rusak $)$

Pengamatan di Laboratorium adalah dengan melakukan identifikasi penyakit yang menyerang tanaman kelapa sawit dengan metode moist chamber dan melihat pathogen secara mikroskopis, mengidentifikasi patogen.

\section{HASIL DAN PEMBAHASAN}

Hasil pengamatan terhadap penyakit tanaman kelapa sawit di desa Tebing Tinggi Kecamatan Mara Sebo Ulu dapat dilihat pada gambar berikut: 
Yuza Defitri, Intensitas dan Persentase Serangan Beberapa Penyakit Utama Pada Tanaman Sawit (Elaeis guineensis Jacq.) di Desa Tebing Tinggi Kecamatan Mara Sebo Ulu Kabupaten Batanghari

\section{Gejala Bercak Daun Sawit}

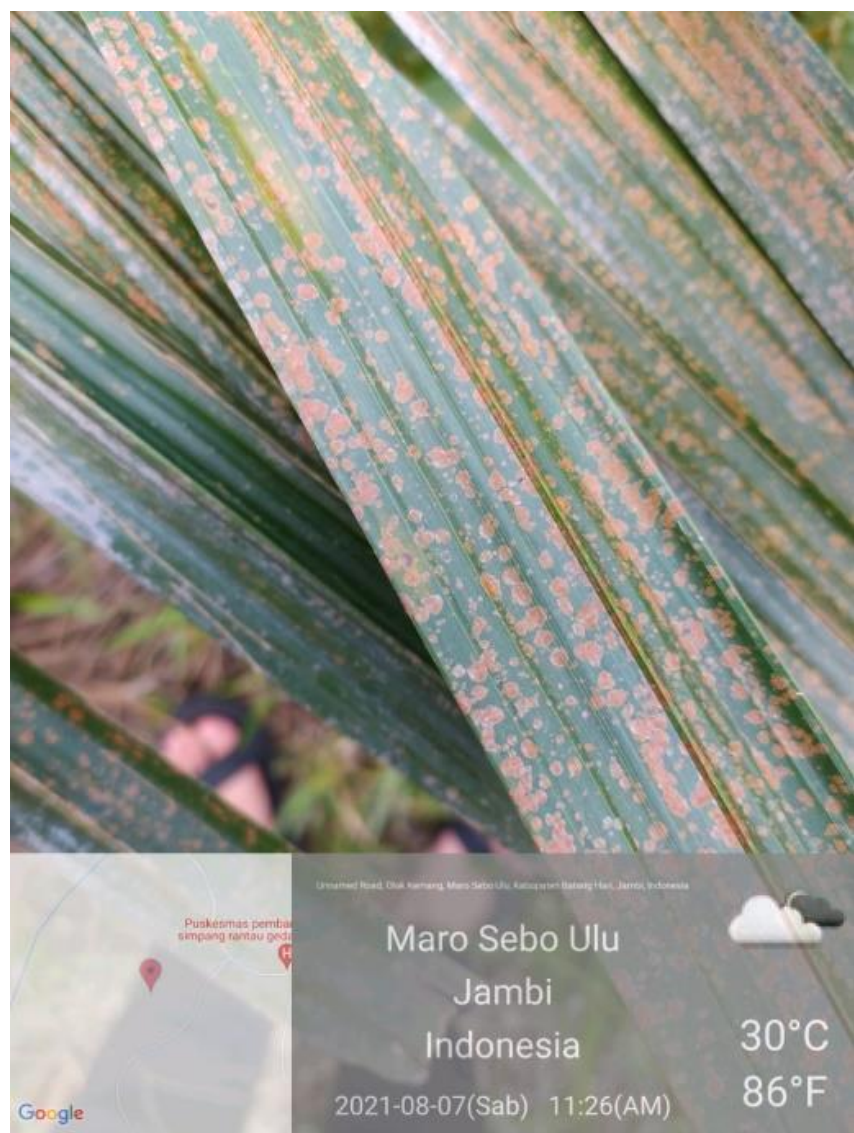

Gambar 1. Gejala bercak daun Curvularia

Bercak daun yang disebabkan oleh Curvularia lebih dikenal sebagai hawar daun curvularia. Gejala yang pertama adalah adanya bercak bilat, kecil, berwarna kuning tembus cahaya yang dapat dilihat di kedua permukaan daun. Pada gejala lanjut bercak menjadi nekrosis, beberapa bercak menyatu membentuk bercak besar tak beraturan. Pada beberapa kasus bagian tengah bercak mengering, rapuh, berwarna kelabu atau coklat muda (Semangun, 2000).

\section{Gejala Penyakit Bercak Daun Drechslera}

Gejala bercak daun Drechslera yaitu adanya bercak kuning kecoklatan sampai kehitaman terdapat pada daun. Gejala prenyakit ini dapat dilihat pada Gambar 3 di bawah ini.

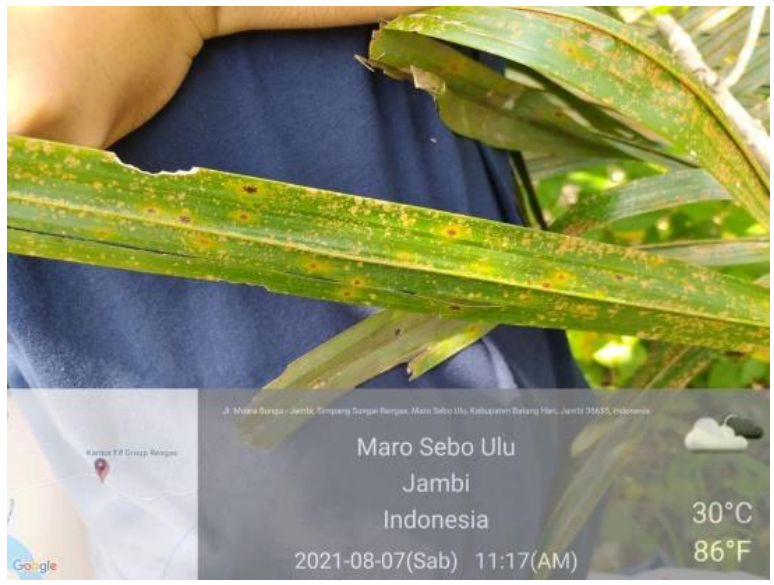

Gambar 2. Gejala Bercak Daun Drechslera

\section{Gejala Penyakit Tajuk (Crown Disease)}

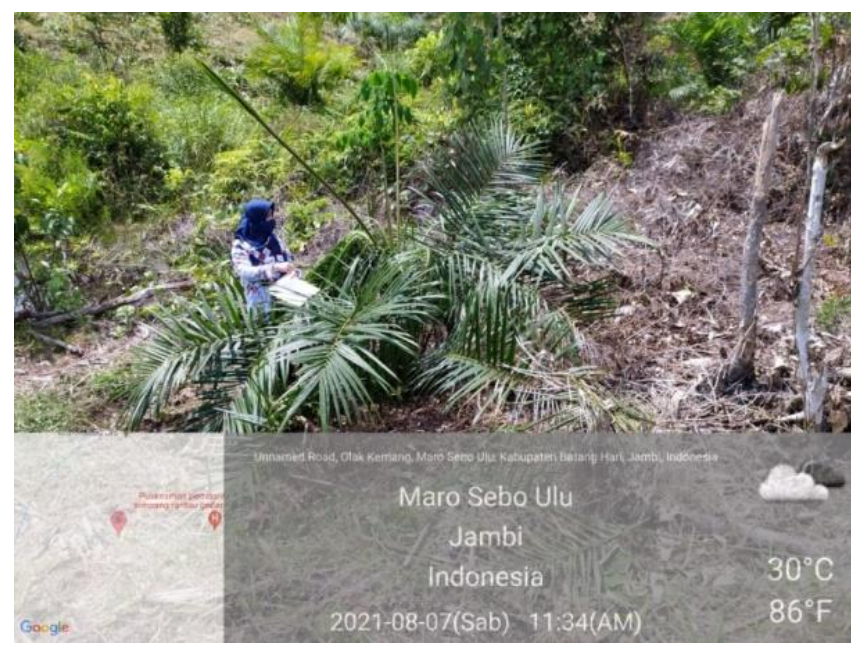

Gambar 3. Gejala Crown Disease pada Tanaman Kelapa Sawit

Penyakit tajuk tanaman (Crown Disease) sering dijumpai di kebun yang belum menghasilkan pada masa TBM 1 sampai TBM 3, dan merupakan penyakit yang paling mencolok disini. Pada umumnya penyakit ini hanya terdapat di kebun yang berumur 1-3 tahun setelah penanaman di lapangan. Sesudah itu penyakit sembuh dengan sendirinya, dan bekas tanaman sakit berkembang seperti tanaman biasa. Meskipun demikian tanaman agak terhambat pertumbuhannya jika dibandingkan dengan tanaman yang tidak mengalami gangguan.Namun umumnya penyakit ini tidak berpengaruh signifikan terhadap penurunan produksi, dibandingkan penyakit tamanan sawit lainnya.

\section{Persentage Serangan penyakit pada tanaman kelapa sawit}

Persentase serangan penyakit tanaman kelapa sawit dapat dilihat pada Tabel 1 seperti di bawah ini. 
Yuza Defitri, Intensitas dan Persentase Serangan Beberapa Penyakit Utama Pada Tanaman Sawit (Elaeis guineensis Jacq.) di Desa Tebing Tinggi Kecamatan Mara Sebo Ulu Kabupaten Batanghari

Tabel 1. Jumlah Dan Persentasi Penyakit Yang Menyerang Tanaman Kelapa sawit Di Desa Tebing Tinggi Kecamatan Mara Sebo Ulu Kabupaten Batanghari

\begin{tabular}{|c|c|c|c|c|c|}
\hline \multirow[t]{2}{*}{ No. } & \multirow[t]{2}{*}{ Jenis Penyakit } & \multirow[t]{2}{*}{ Gejala Penyakit } & \multicolumn{3}{|c|}{$\begin{array}{c}\text { Jumlah dan Persentase Tanaman } \\
\text { Terserang Penyakit } \\
\end{array}$} \\
\hline & & & P1 & $\mathrm{P} 2$ & P3 \\
\hline 1 & Bercak Daun Curvularia & $\begin{array}{l}\text { Pada daun ada bercak berwarna kuning } \\
\text { kecoklatan merata pada daun sawit. }\end{array}$ & $\begin{array}{l}7 \text { pohon } \\
35 \%\end{array}$ & $\begin{array}{l}8 \text { pohon } \\
40 \%\end{array}$ & $\begin{array}{l}3 \text { pohon } \\
15 \%\end{array}$ \\
\hline 2 & Bercak Daun Drechslera & $\begin{array}{l}\text { Terdapatnya bercak daun berwarna kuning } \\
\text { kecoklatan sampai kehitaman. }\end{array}$ & $\begin{array}{l}6 \text { pohon } \\
30 \%\end{array}$ & $\begin{array}{l}7 \text { pohon } \\
35 \%\end{array}$ & $\begin{array}{l}3 \text { pohon } \\
15 \%\end{array}$ \\
\hline 3 & $\begin{array}{l}\text { Penyakit Tajuk (Crown } \\
\text { Disease) }\end{array}$ & $\begin{array}{l}\text { pada tanaman muda yang sakit banyak daun yang } \\
\text { bengkok ke bawah di tengah pelepahnya. ini tidak } \\
\text { terdapat anak daun atau anak daunnya kecil, } \\
\text { robek-robek. gejala ini mulai tampak pada janur... }\end{array}$ & $\begin{array}{l}0 \text { pohon } \\
0 \%\end{array}$ & $\begin{array}{l}0 \text { pohon } \\
0 \%\end{array}$ & $\begin{array}{l}4 \text { pohon } \\
20 \%\end{array}$ \\
\hline
\end{tabular}

P1, P2 dan P3 lokasi pengambilan sampel,

Berdasarkan Tabel 1, jenis penyakit yang ditemukan pada seluruh lahan yang diamati ada tiga penyakit yaitu Bercak Daun Curvularia, Bercak Daun Drechslera dan Penyakit Tajuk (Crown Disease).

Penyakit bercak daun Curvularia yang diakibatkan oleh jamur Curvularia sp pada lahan P1 terdapat 7 (35 \%) tanaman yang terserang penyakit, pada lahan P2 terdapat $8(40 \%)$ tanaman yang terserang penyakit dan pada lahan P3 terdapat 3 tanaman (15\%) yang terserang penyakit. Sedangkan penyakit bercak daun Drechslera yang disebabkan jamur Drechslera sp ditemukan juga di tiga lokasi yaitu pada lahan P1 terdapat $6(30 \%)$ tanaman terserang penyakit, pada lahan P2 terdapat $7(35 \%)$ tanaman terserang dan pada lahan P3 terdapat $3(15 \%)$ tanaman terserang penyakit. Penyakit Tajuk (Crown Disease) tidak ditemukan pada lahan P1 dan P2 tetapi hanya ditemukan pada lahan P3. Hal ini disebabkan karena pada lahan P1 dan P2 adalah tanaman kelapa sawit yang telah berumur 19 - 20 tahun sedangkan lahan P3 adalah lahan replanting yang masih berumur $4-5$ tahun. Lahan P1 dan P2 banyak terserang penyakit bercak daun Curvularia dan bercak daun Drechslera karena pada saat sekarang di lahan tersebut kurang dilakukan pemeliharaan terhadap tanaman kelapa sawit misalnya membuang atas membasmi gulma. Pada lahan P3 dominan diserang penyakit tajuk (Crown Disease) karena tanaman sawit yang muda berumur $4-5$ tahun peka terhadap serangan penyakit tersebut sekitar $20 \%$.

\section{Intensitas serangan penyakit pada tanaman kelapa sawit}

Intensitas serangan penyakit pada tanaman kelapa sawit di desa Tebing Tinggi dapat dilihat pada tabel 2

Tabel 2. Intensitas Serangan Penyakit Bercak Daun Curvularia, Bercak Daun Drechslera dan Penyakit Tajuk Crown Disease di Desa Tebing Tinggi Kecamatan Mara Sebo Ulu Kabupaten Batanghari

\begin{tabular}{lccccc}
\hline \multirow{2}{*}{ Nama Penyakit } & \multicolumn{3}{c}{ Inensitas serangan $(\%)$} & \multirow{2}{*}{ Total } & \multirow{2}{*}{ Rerata } \\
\cline { 2 - 4 } & P1 & P2 & P3 & & 26,25 \\
Bercak Daun Curvularia & 28,75 & 35.00 & 15,00 & 78,75 & 23,75 \\
Bercak Daun Drecshlera & 26,25 & 30.00 & 15.00 & 71,25 & 06,60 \\
Crown Disease & 00,00 & 00.00 & 20.00 & 20,00 & \\
\hline
\end{tabular}

Berdasarkan data pada Tabel 2, menunjukkan bahwa intensitas serangan penyakit Bercak Daun Curvularia yang disebabkan jamur Curvularia sp di desa Tebing Tinggi adalah 26,25 \%, intensitas penyakit Bercak Daun Drecshlera yang disebabkan jamur Drechslera sp adalah 23,75\% dan intensitas penyakit Tajuk Crown Disease adalah 6,6 \%. Menurut Abadi, (2005) Pada umumnya lahan perkebunan tanaman kelapa sawit yang berumur antara 14 - 20 tahun banyak terserang penyakit Bercak Daun Curvularia dan Bercak Daun Drecshlera. Pada lahan perkebunan tanaman kelapa sawit berumur $1-5$ tahun itu banyak terserang penyakit Tajuk Crown Disease.

Hasil pengamatan di laboratorium ditemukan tiga jenis jamur yang menyerang tanaman kelapa sawit di lokasi penelitian yaitu seperti yang terlihat pada gambar berikut ini :

\section{Jamur Curvularia sp}

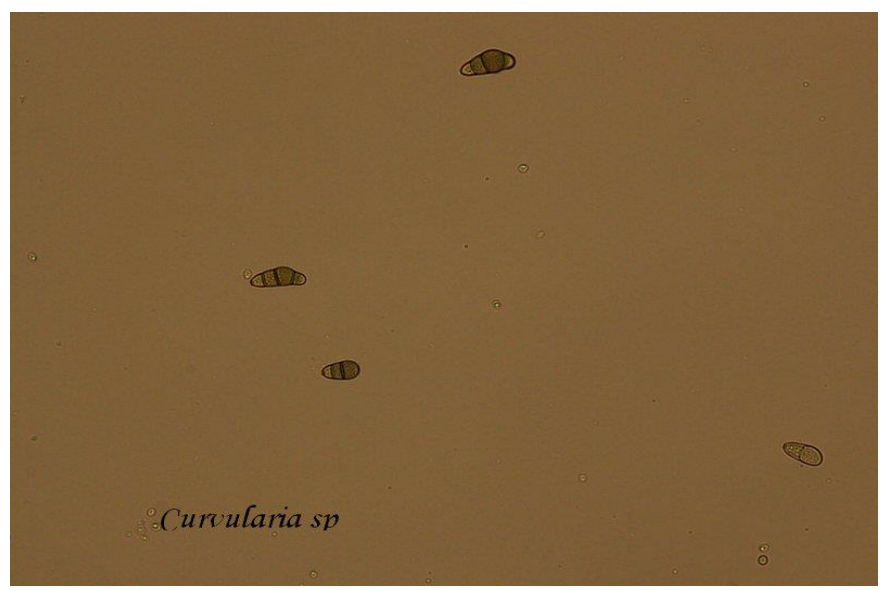

Gambar 4. Konidia Jamur Curvularia sp 
Yuza Defitri, Intensitas dan Persentase Serangan Beberapa Penyakit Utama Pada Tanaman Sawit (Elaeis guineensis Jacq.) di Desa Tebing Tinggi Kecamatan Mara Sebo Ulu Kabupaten Batanghari

Beberapa spesies Curvularia sp kebanyakan konidiumnya bersekat 3 dan 4 , dengan dua sel yang lebih besar dan lebih gelap, sedikit bengkok (Semangun, 2000).

\section{Jamur Drechslera sp}

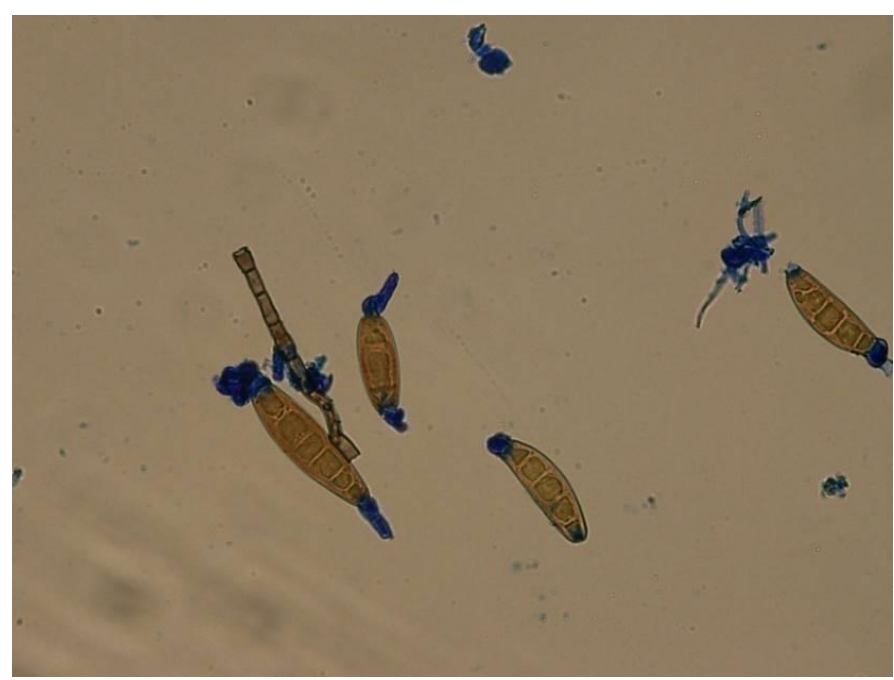

Gambar 5. Konidia Jamur Drechslera sp

Menurut Ou dalam Semangun (2000), konidia bentuknya sedikit melegkung (kurva), membesar dibagian tengah dengan ukuran35 - $170 \times 11-17 \mu \mathrm{m}$, jumlah septa mencapai 13.. Konidia yang telah masak tumbuh pada kedua ujung konidia. Jamur patogen penyakit bercak coklat adalah Cocliobolus miyabeanus. (Drechslera $\mathrm{sp}$ ).

\section{Konidia Jamur Fusarium sp}

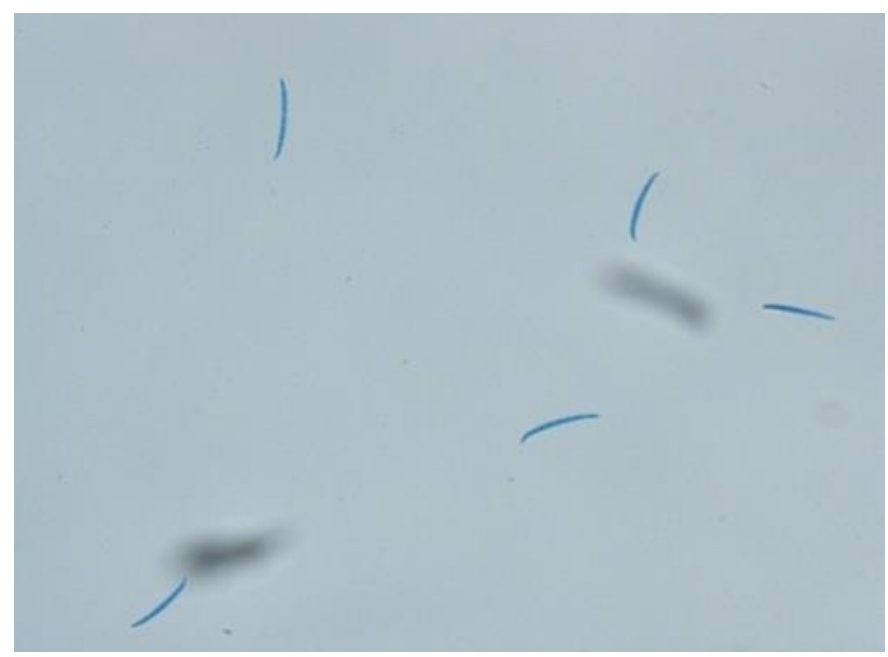

Gambar 6. Konidia jamur Fusarium sp

Fusarium sp memiliki koloni yang berwarna putih atau disertai warna ungu hingga merah muda pada setiap koloninya. Selain itu, koloni jamur ini akan 8 menghasilkan warna berbeda pada isolat dengan media tumbuh yang sama. Hal tersebut dikarenakan jamur Fusarium sp mudah mengalami mutasi sehingga warna koloni tidak dapat dijadikan sebagai parameter identifikasi (Sinaga, 2004).

Koloni Fusarium sp umumnya memiliki mikrokonidium dengan jumlah yang sangat banyak dan bersel tunggal dan berbentuk oval, berdinding tebal dan halus dengan apikal sel yang runcing pada bagian bawahnya. Sedangkan konidiofor pada Fusarium oxysporum merupakan tangkai yang pendek (Sinaga, 2004).

\section{SIMPULAN}

Dari penelitian yang telah dilakukan di Desa Tebing Tinggi Kecamatan Mara Sebo Ulu Kabupaten Batanghari dapat ditarik kesimpulan bahwa ditemukan tiga penyakit pada tanaman kelapa sawit yaitu bercak daun Curvularia yang disebabkan jamur Curvularia sp, bercak daun Drechslera yang disebabkan jamur Drechslera sp dan penyakit tajuk (Crown Desease) yang disebabkan jamur Fusarium sp.

Ditemukan beberapa Persentase serangan penyakit yaitu , penyakit bercak daun Curvularia yang tertinggi ditemukan di lahan P2 sebesar $40 \%$, persentase serangan penyakit bercak daun Drechslera tertinggi ditemukan dilahan P2 sebesar 35\% dan persentase serangan penyakit tajuk (Crown Desease) tertinggi ditemukan di lahan P3 yaitu $20 \%$.

Adapun Intensitas serangan penyakit yang ditemukan di Desa Tebing Tinggi yaitu, intensitas serangan penyakit Bercak Daun Curvularia yang disebabkan jamur Curvularia sp di desa Tebing Tinggi adalah 28,75 \%, intensitas penyakit Bercak Daun Drecshlera yang disebabkan jamur Drechslera sp adalah $26,25 \%$ dan intensitas penyakit Tajuk Crown Disease adalah $6,6 \%$. .

\section{DAFTAR PUSTAKA}

Abadi, A. 2005. Ilmu Penyakit Tumbuhan.. Bayu Media Jakarta

Agrios, G. 1999. Ilmu Penyakit Tumbuhan. Gajah Mada University Press Jogyakarta.

Biro Pusat Statistik Jambi, 2018. Jambi Dalam Angka, Jambi.

Semangun, H. 2000. Penyakit-Penyakit Tanaman Perkebunan di Indonesia. Gajah Mada University Press Jogyakarta.

Sianturi, H. 2001. Budidaya Kelapa Sawit. Fakultas Petanian USU, Medan

Sinaga, M. 2004. Dasar-dasar Ilmu Penyakit Tumbuhan. Penebaran Swadaya Jakarta.

Sitinjak, R. R. (2018). Respon pertumbuhan bibit kelapa sawit (elaeis guineensis jacq.) Di pre nursery setelah pemberian ekstrak bawang merah (allium cepa 1.) Dengan waktu perendaman yang berbeda. Agroprimatech, 2(1), 1-9. 